\title{
Developing extra-long Grain, Early Maturing and High Yielding Basmati Rice Variety for Flood-Prone Areas of Pakistan
}

\author{
Muhammad Akhter, Abid Mahmood, Zulqarnain Haider, Tahira Bibi and Rana Ahsen Raza Khan \\ Rice Research Institute, Kala Shah Kaku, Lahore, Pakistan \\ Email: z.haider.breeder@gmail.com
}

\begin{abstract}
High-yielding and quality grain rice varieties with submergence tolerance has now become foremost objective of rice breeding research world-wide after loss of thousands of acres due to frequent floods for last five years. New flood tolerant, fertilizer-responsive, high yielding varieties can increase income of poor farmers in the face of considerable rise in floods and world population. To cope with this situation, a new improved high yielding, extra-long grain variety also suitable for flood-prone areas of Pakistan was developed. The variety named as Chenab Basmati was bred by hybridizing line 98PP4 with line 4439 during 1998-99. The pedigree method of selection continued up to seventh filial generation at Rice Research Institute Kala Shah Kaku, Pakistan. The selection was accompanied with marker assisted selection in MAS lab; whereas phenotypic field screening in submergence tank constructed at RRI KSK. It was tested in fine grain yield trials and regional adaptability trials to compare this improved candidate variety with Super Basmati and Basmati 515 as checks. The overall average yield of Chenab Basmati in all the in-station and out-station yield trials was $4.52 \mathrm{t} / \mathrm{ha}$ in comparison with $3.65 \mathrm{t} / \mathrm{ha}$ of Super Basmati and $3.90 \mathrm{t} / \mathrm{ha}$ of Basmati 515. It was observed that the advanced line showed a yield advantage of $24 \%$ and $16 \%$ over check varieties i.e., Super Basmati and Basmati 515, respectively. Among grain quality attributes, its head rice recovery $(58 \%)$ and grain length $(7.61 \mathrm{~mm})$ were found better than checks. Chenab Basmati showed tolerance index of more than 0.9 during both the years indicating its potential to be used as flood tolerant variety.
\end{abstract}

Keywords: Oryza sativa, rice variety, high yielding, flood tolerant, early maturing, extra-long grain

\section{Introduction}

Rice (Oryza sativa L.) is critical for human nourishment because it serves as basic food for more than two billion people $(\sim 60 \%$ of the world population). It provides more calories than any other food crop (Khush, 2005). Rice is playing a vibrant role in Pakistan's economy as it is the second staple food after wheat and largest foreign exchange earning agricultural commodity. It accounts for $3 \%$ in value added in agriculture and $0.6 \%$ of gross domestic product (Economic survey of Pakistan, 2016-17). In Asia, 90\% of the world rice is produced and consumed. International rice export is dominated by a few countries such as India, Thailand, Vietnam and Pakistan, as they contribute around $60-70 \%$ in total world export (Memon, 2013). Pakistan holds 5th position among top ten rice exporting countries. Out of 6.850 million metric tons produced during 2016-17 (P), 4.20 million metric tons were exported earning valuable foreign exchange of US\$ 1.860 billion (Rice exports by countries by Daniel Workman, April 13, 2017).

Continuous progress in rice breeding and production technology has helped Pakistan to fulfil the rising local and international demands. However, the country is experiencing large annual variation in rice production because of water scarcity, slow research progress and non-availability of new or quality seed. During 2017, around 14\% decline in rice export was observed compared to previous year due to high input costs, low production and high local consumption. Therefore, replacement of low-yielding rice genotypes with promising, efficient and higher yielding basmati cultivars can be a viable option to fetch premium benefits.

Basmati is the most sought-after special type of rice grown in Pakistan and India that is internationally eminent due to its cooking quality parameters. Considering its uniqueness, goodwill among growers and consumers, and changing dietary needs, the demand of such rice type is increasing worldwide (Ghasal et al., 2015). Punjab province is the major producer of basmati rice due to its soil and agro-climatic conditions sharing $70 \%$ in total production. The main basmati production areas 
include Gujranwanala, Hafizabad, Nankana Sab, Narrowal, Sheikhupura and Sialkot districts. In recent years, hybrid rice cultivars had greatly influenced the basmati production because of their short maturity duration and better yields, that's why basmati production is showing decreasing trend in recent years (Abedullah et al., 2007). Moreover, rice growers and traders has different interests as farmers want early maturing and higher yielding cultivars which provide them maximum profit and enough time for sowing of next crops, whereas traders prefer better grains in terms of aroma, colour, shape, size and texture (Khan \& Khan, 2010).

The traditional basmati cultivars are susceptible to lodging, diseases, photoperiod, temperature and are lower yielding when compared to non-basmati cultivars (Verma et al., 2017). During 1920's, the basmati rice improvement programme was initiated at Rice Research Institute Kala Shah Kaku (RRI KSK), Pakistan (Ahmad et al., 2005). New basmati cultivars possessing higher genetic yield potential, better grain quality parameters, resistance to lodging and different diseases were long awaited. The earlier attempts had limited success due to lack of infrastructure for grain quality evaluation and well defined selection criteria. The varieties developed through pure line selections were good for cooking quality traits but were susceptible to lodging, diseases, insects and had lower yielding potential (Inayatullah et al., 1986; Shobha, 2009). The main hurdle in Basmati improvement programme lies in pooling of aroma and grain quality parameters with acceptable agronomic features (Khush \& Juliano, 1991). Super Basmati replaced Basmati 385 and Basmati 370 due to its higher yield potential and better grain quality but had weak stem stiffness along with higher insect incidence rates (Akhtar et al., 2014; Akhtar et al., 2015). Super Basmati is still popular among local farmers, however, its demand has been decreasing in International markets as international buyers are now demanding extra-long grain varieties with acceptable cooking qualities (Khan \& Khan, 2010; Jafar et al., 2015). Furthermore, the farmers of traditional rice area are demanding an early maturing, high yielding and lodging resistant basmati rice varieties with good grain quality and resistance to different diseases. Under this scenario, scientists at RRI KSK have developed an early maturing, stiff stemmed, higher yielding and extra-long grain rice variety "Chenab Basmati".

\section{$2 \quad$ Material and Methods}

Chenab Basmati has been evolved by crossing line 98PP4 with line 4439 as a donor of trait for submergence tolerance during the year 1998. Line 98PP4 is a high yielding with long grain and good quality characters, whereas line 4439 is also high yielding, early and short stature and possessed the character of submergence tolerance under flooded condition. The pedigree method of selection continued up to F7 generation with the pedigree No. PK8431-1-2-1-2-4. It was tested in observational plot during 2010, fine grain yield trials and regional adaptability trials at various locations of Punjab, Pakistan from 2011 to 2015. This new candidate variety Chenab Basmati along with Super Basmati and Basmati 515 was tested in 13 trials under two national uniform rice yield trials during 2013 and 2014. During two years, 2014 and 2015, the line was also tested in artificial submergence tank constructed at research area of RRI KSK for submergence stress of about 14 days following protocol developed by International Rice Research Institute, Philippines.

To ascertain the best transplanting date, the variety was passed through transplanting date trials for two consecutive years from 2014-2015. Likewise, to find the best ratio of N-P-K application, a trials were conducted during 2013. To measure the susceptibility and resistance of the variety against diseases (bakanae/ foot rot, bacterial leaf blight, blast and stem rot) and insect pests (stem borer and leaf folder), trials were also conducted along with super basmati and basmati 515 checks.

Data of agronomic traits (yield, maturity days, height, tillers, grain shape traits such as grain length, width, thickness of both grain and paddy), cooking quality parameters (boiled kernel length, cooked grain length, elongation ratios), milling (husk \%,bran $\%$, total recovery $\%$, head rice recover $\%$, broken \%), nutritional parameters (amylose contents, alkali spread value and aroma) were also measured during all the trials to evaluate the consistency and uniformity of these traits in the successive generations. Quality index was calculated to evaluate and compare the ultimate quality of the newly evolved variety with that of the existing varieties of rice as checks. 


\subsection{Field Screening for Submergence / Flood Tolerance}

One hundred and fifteen (115) rice genotypes including Chenab Basmati, six (06) local cultivars/ released varieties and three high yielding varieties i.e. Sabitri, IR6 and NSICRC222 being used as potential variety in many countries of Asia, were used as experimental material. All these genotypes were evaluated in a natural water pond that allows maintenance of water depth of $150 \mathrm{~cm}$ for a period of 15 days. The experiment was laid out in a triplicated randomized complete block design (RCBD). Seeds were sown on the wet raised beds and 21 days seedlings were transplanted to well puddle soil in the deep pond/ submergence tank at $20 \mathrm{~cm} \times 20 \mathrm{~cm}$ with two seedlings per hill. Plot size was maintained in two rows of $5 \mathrm{~m} 2$ length for each entry. Non-experimental lines of Super Basmati were also planted on each side of the pond to observe the damages due to submergence. Nitrogen fertilizer was applied at 30:30:30 kg/ha as basal dose a day before starting transplanting. Gap-filling was also practice as required 7 days after transplanting (DAT) in order to ensure $100 \%$ plant establishment. Plants were counted before applying submergence stress. The transplanted seedlings were allowed to establish their roots for 20 DAT before submergence. The pond was filled with normal canal water up to depth level of $1500 \mathrm{~cm}$ so that all the plants of all the entries were completely submerged within a day. The same water depth was maintained for the period of 14 days by adding water regularly. After completing 14 days of complete submergence, the treatment was terminated. The water was drained out of pond to water level of 1-2 cm. After a day, the water was again filled up to a level of $5 \mathrm{~cm}$. Second split of nitrogen fertilizer was applied at the rate of $30 \mathrm{~kg} / \mathrm{ha}$ after 10 days and the third split of $30 \mathrm{~kg} / \mathrm{ha}$ was applied after 20 days of second split. All the following agronomic and plant protection measures were adopted as normal in order to allow the plant to recover from submergence stress.

\section{$3 \quad$ Results and Discussion}

Thirty-three (33) trials were conducted to compare new variety, Chenab Basmati with Super Basmati and Basmati 515. The overall average yield of Chenab Basmati was $4.52 \mathrm{t} /$ ha against $3.65 \mathrm{t} / \mathrm{ha}$ of Super Basmati and $3.90 \mathrm{t} / \mathrm{ha}$ of Basmati 515. Results of fine grain yield trial, adaptability trials and National Uniform Rice Yield trials clearly showed the superior yield performance of Chenab basmati variety over checks i.e. Super Basmati and Basmati-515. Chenab Basmati has a yield advantage of $24 \%$ and $16 \%$ over standard check varieties i.e., Super Basmati and Basmati 515, respectively (Table 1). Chenab basmati is also moderately resistant to stem rot and paddy blast diseases (Table 2) while Super Basmati and Basmati-385 are highly susceptible to these diseases.

Table 1. Description of Basmati 515 in comparison with existing commercial variety Super Basmati

\begin{tabular}{lccc}
\hline Characters & \multicolumn{3}{c}{ Name of variety } \\
\cline { 2 - 3 } Paddy & Chenab Basmati & Super Basmati & Basmati 515 \\
Paddy Length (mm) & 11.25 & 10.75 & 10.78 \\
Paddy Width (mm) & 1.82 & 1.78 & 1.85 \\
Paddy Thickness (mm) & 1.56 & 1.66 & 1.72 \\
Rice kernel & & & \\
kernel Length (mm) & 7.61 & 7.44 & 7.56 \\
kernel Width (mm) & 1.53 & 1.62 & 1.44 \\
kernel Thickness (mm) & 1.45 & 1.51 & 1.28 \\
Head rice \% & 58.0 & 54.0 & 53.5 \\
Amylose content \% & 22.2 & 23.80 & 23.45 \\
Plant height (cm) & 122 & 125 & 132 \\
Grains per panicle & 158 & 88 & 131 \\
1000 grain weight (gm) & 21.04 & 20.81 & 20.13 \\
Maturity days & 107 & 113 & 114 \\
Avg. yield (t/ha) & 4.52 & 3.39 & 3.90 \\
\hline
\end{tabular}


Table 2. Comparison of Basmati 515 with existing commercial variety Super Basmati in all trials on average basis

\begin{tabular}{|c|c|c|c|c|c|}
\hline \multirow[t]{2}{*}{ Name of trial } & \multicolumn{3}{|c|}{ Paddy Yield (t/ha) } & \multicolumn{2}{|c|}{ Yield advantage over checks } \\
\hline & $\begin{array}{l}\text { Chenab } \\
\text { Basmati }\end{array}$ & $\begin{array}{c}\text { Super } \\
\text { Basmati }\end{array}$ & $\begin{array}{c}\text { Basmati } \\
515 \\
\end{array}$ & $\begin{array}{c}\text { Super } \\
\text { Basmati }\end{array}$ & Basmati 515 \\
\hline Varietal yield trials & 4.91 & - & 4.27 & - & $+14.9 \%$ \\
\hline Micro plot yield trials & 4.41 & - & 3.83 & - & $+15.0 \%$ \\
\hline $\begin{array}{l}\text { Regional Adaptability } \\
\text { Trials (NURYT) }\end{array}$ & 4.53 & 3.65 & 3.74 & $+24.0 \%$ & $+21.1 \%$ \\
\hline Sowing date trials & 4.22 & - & 3.76 & - & $+12.3 \%$ \\
\hline Total & 4.52 & 3.65 & 3.90 & $+24 \%$ & $16 \%$ \\
\hline
\end{tabular}

Chenab Basmati was tested in observational plot during 2010. The table shows that the new candidate variety, Chenab Basmati gave significantly higher paddy yield (6.24 \%) than Super Basmati in Observational Plots (OPs). Varietal trials were conducted at Rice Research Institute, Kala Shah Kaku from 2011 to 2013 to assess the yield performance of new candidate line on station. The results showed that the new variety, Chenab Basmati gave significantly higher paddy yield $(14.9 \%$ on the average of 3 years) than Basmati 515 in station yield trials.

The new variety Chenab Basmati along with Basmati 515 was tested in nine (9) Micro Plot Yield Trial / Regional Adaptability Yield trials (Figure 1). The maximum yield was obtained at Kala Shah Kaku. The results indicate that the Chenab Basmati gave significantly higher paddy yield (15\% on the average of two years) than Basmati 515 in micro plot yield trials. The new candidate variety Chenab Basmati along with Super Basmati and Basmati 515 was tested in 13 locations under National Uniform Rice Yield Trial (NURYT) trials in two years (Figure 2). The yield data indicates that the paddy yield advantage of Chenab Basmati was $24 \%$ and $21 \%$ over check varieties Super Basmati and Basmati 515, respectively in National Uniform Rice Yield Trials (NURYT) conducted during both the years.

Yield data of transplanting trials on Chenab Basmati and Super Basmati conducted at Rice Research Institute, Kala Shah Kaku during 2014 \& 2015 given in Table 3. It is quite clear from the data that on average of two years, yield performance of Chenab Basmati was better for 30th June and 20th July transplanting dates. Therefore, it is obvious that optimum time for transplanting rice nurseries of Chenab Basmati ranges from 1st to 20th July. Fertilizer trial on Chenab Basmati was conducted at Rice Research Institute, Kala Shah Kaku during 2013. The average paddy yield with different doses of fertilizer is given in Table 4.

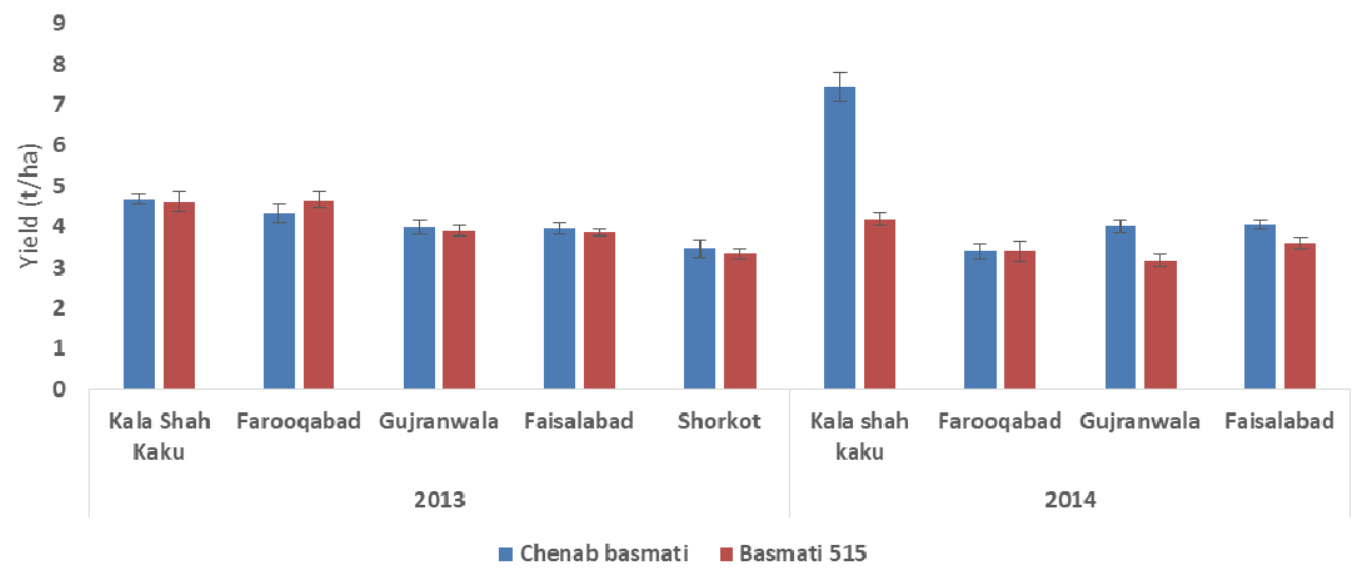

Figure 1. Comparison of Chenab Basmati and Basmati 515 in Adaptability Trials at different locations for two years 


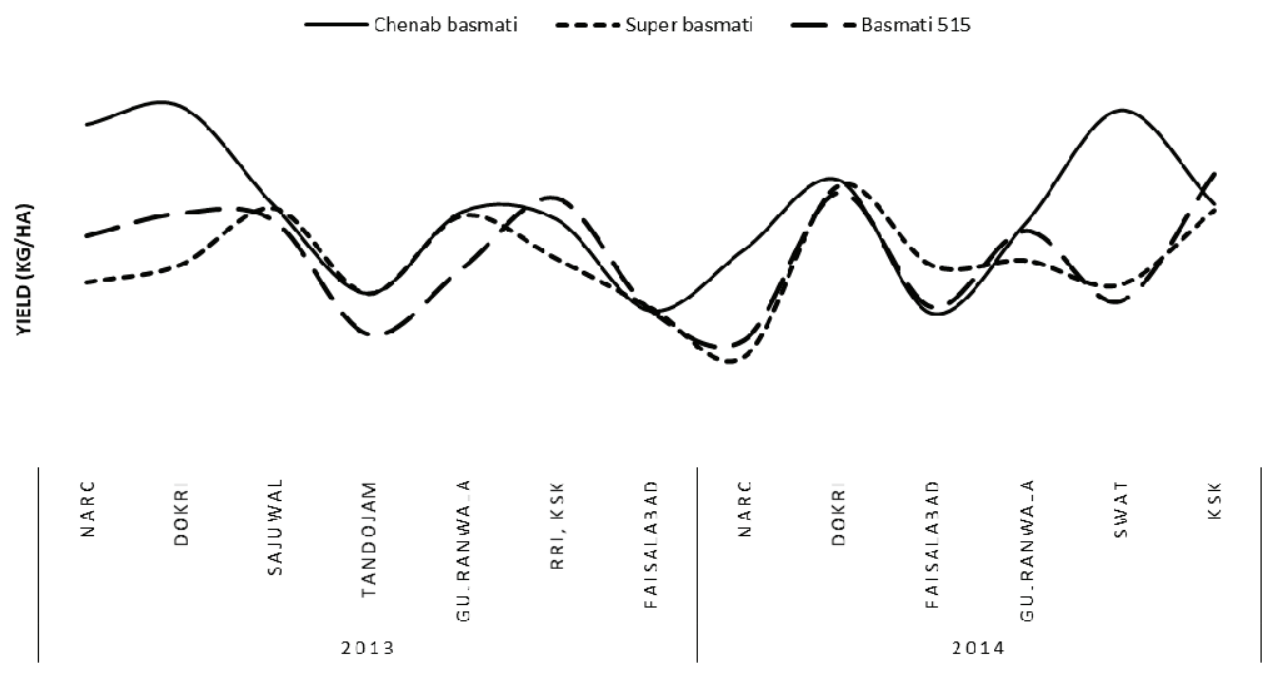

Figure 2. Comparison of Chenab Basmati with checks in National adaptability trials for two years

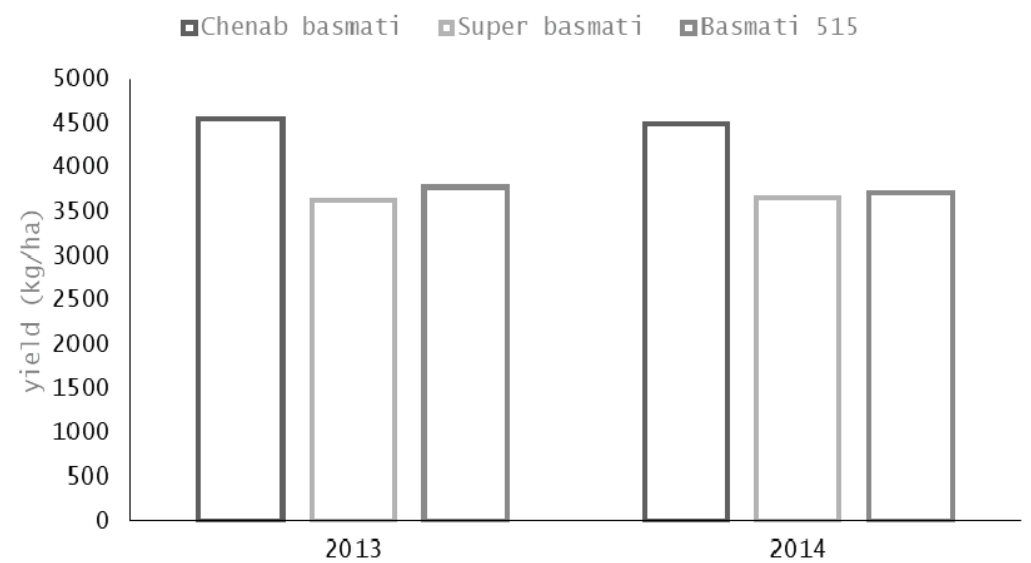

Figure 3: Average yield comparison Chenab Basmati with check varieties in adaptability yield trials during both years

Table 3. Comparison of Basmati 515 with existing commercial variety Super Basmati in sowing date trials conducted at RRI, KSK during 2006-2009.

\begin{tabular}{|c|c|c|c|c|c|}
\hline \multirow[t]{2}{*}{ Year / Variety } & \multicolumn{5}{|c|}{ Transplanting dates / paddy yield ( $\mathrm{t} / \mathrm{ha}$ ) } \\
\hline & $1 / 6$ & $30 / 6$ & $20 / 7$ & $6 / 8$ & Average \\
\hline \multicolumn{6}{|l|}{2014} \\
\hline Chenab Basmati & 3.26 & 5.40 & 5.53 & 3.26 & $4.36 \mathrm{~A}$ \\
\hline Basmati 515 & 2.88 & 3.21 & 4.05 & 3.98 & $3.53 \mathrm{C}$ \\
\hline LSD var. $(0.05)$ & 0.44 & & & & \\
\hline \multicolumn{6}{|l|}{2015} \\
\hline Chenab Basmati & 3.70 & 4.44 & 5.77 & 3.42 & $4.33 \mathrm{~A}$ \\
\hline Basmati 515 & 3.41 & 4.27 & 5.50 & 3.36 & $4.14 \mathrm{~B}$ \\
\hline LSD var. $(0.05)$ & 0.13 & & & & \\
\hline \multicolumn{6}{|c|}{ Average of two years } \\
\hline Chenab Basmati & 3.48 & 4.92 & 5.65 & 3.34 & 4.34 \\
\hline
\end{tabular}




\begin{tabular}{lccccc}
\hline Basmati 515 & 3.15 & 3.74 & 4.78 & 3.67 & $\mathbf{3 . 8 3}$ \\
\hline YIELD ADVANTAGE OF CHENAB BASMATI & OVER BASMATI & B15 & $+\mathbf{1 2}$ \\
\hline
\end{tabular}

Table 4. Comparing suitable dose of NPK fertilizer for Chenab Basmati

\begin{tabular}{cc}
\hline Treatment NPK $(\mathrm{kg} / \mathrm{ha})$ & Paddy yield (t/ha) \\
\hline $00-00-00$ & $2.831 \mathrm{c}$ \\
\hline $110-85-62$ & $3.336 \mathrm{~b}$ \\
\hline $133-85-62$ & $3.992 \mathrm{a}$ \\
\hline $156-85-62$ & $4.107 \mathrm{a}$ \\
\hline $179-85-62$ & $4.118 \mathrm{a}$ \\
\hline
\end{tabular}

*Treatments with different letters differ significantly at $5 \%$ probability $(\mathrm{p} \leq 0.05)$

The results given in Table 4 depict that fertilizer treatment $133-85-62 \mathrm{~kg} / \mathrm{ha}$ is economical. Pest population was recorded at Rice Research Institute, Kala Shah Kaku under non-sprayed conditions for three years i.e., 2011, 2012 and 2013.Pest population data recorded showed that Chenab Basmati was moderately resistant to Stem Borer while moderately susceptible to Leaf folder. Super Basmati and Chenab Basmati were tested during 2011, 2012 and 2013 against paddy blast, bacterial leaf blight and stem rot at Rice Research Institute, Kala Shah Kaku.

Results showed that the new candidate variety Chenab Basmati was moderately susceptible to Bacterial Leaf Blight (BLB), Paddy Blast and Stem rot whereas Super Basmati was susceptible to all the studied diseases. Chenab Basmati and Super Basmati were tested during 2011 and 2012 against Bacterial Leaf Blight, Paddy Blast and Stem rot by National Agriculture Research Center, Islamabad. Results showed that the new candidate variety Chenab Basmati was susceptible to Bacterial Leaf Blight, moderately susceptible to Paddy Blast and moderately resistant to stem rot whereas Super Basmati was susceptible to Bacterial Leaf Blight, highly susceptible to Paddy Blast and moderately susceptible to stem rot.

\subsection{Field Screening for Submergence / Flood Tolerance}

The obtained results clearly indicated that all the genotypes with submergence tolerant gene (SUB1) showed significantly greater tolerance level as compared to other local cultivars/ varieties, authenticating the effectiveness of SUB1 QTL in conferring submergence tolerance. However, a significant variation was observed among the studied cultivars in tolerance for submergence as well as all other traits studied. Chenab Basmati showed tolerance index of more than 0.9 during both the years indicating its potential to be used as flood tolerant variety.

\section{Conclusion}

The overall average yield of Chenab Basmati in all the in-station and out-station yield trials was 4.52 t/ha in comparison with $3.65 \mathrm{t} /$ ha of Super Basmati and $3.90 \mathrm{t} / \mathrm{ha}$ of Basmati 515 . It is very clear that the candidate line has a yield advantage of $24 \%$ and $16 \%$ over check varieties i.e., Super Basmati and Basmati 515, respectively. This variety was additionally found to be tolerant to submergence stress while moderately susceptible to Bacterial Leaf Blight (BLB), Paddy Blast and Stem rot. Among grain quality attributes, its head rice recovery (58\%) and grain length $(7.61 \mathrm{~mm})$ were found better than checks. The variety exhibited adequate potential to be used as cultivar for yield augmentation and income returns.

\section{References}

1. Abedullah KS, Mushtaq K (2007) Analysis of technical efficiency of rice production in Punjab (Pakistan): Implications for future investment strategies. Pakistan Economic and Social Review: 231-244. 
2. Ahmad M, Akhtar M, Anwar M (2005) Basmati rice: progress, issues and prospects for Pakistan. In Proceeding of the international seminar in rice crop (pp. 1-7).

3. Akhtar M, Akhtar MS, Haider Z (2015) PK 386: A new high yielding, early maturing, long grain rice (Oryza sativa L.) variety. J. Agric. Res, 53(3).

4. Akhtar M, Akhtar MS, Rizwan M (2014) Basmati-515: A new variety with extra-long grain for productivity augmentation in Punjab, Pakistan. J. Agric. Res, 52(1).

5. Daniel Workman, April 13, 2017. Rice exports by countries.

6. Economic survey of Pakistan. 2016-17. Economic Advisor's Wing, Ministry of. Finance, Islamabad.

7. Ghasal PC, Shivay YS, Pooniya V (2015) Response of basmati rice (Oryza sativa) varieties to zinc fertilization. Indian Journal of Agronomy, 60(: .403-409.

8. Inayatullah C, Rehman A, Ashraf M (1986) Management of insectpests of paddy in Pakistan. Progressive Farming 6:54-62.

9. Jafar RMS, Rabnawaz A, Hussain S, Ahmed W, Zhuang P (2015) Aptitudes of Pakistani Rice Industry with Respect to Global Trade.

10. Khan MA, Khan SL (2010) Report on Potential Markets of RICE. Trade Development Authority of Pakistan: pp.14.

11. Khush GS (2005) What it will take to Feed 5.0 billion rice consumers in 2030. Plant Molecular Biology 59:1-6.

12. Khush GS, Juliano BO (1991) Research priorities for improving rice grain quality. In: Rice Grain Marketing and Quality Issues IRRI, Los, Banos, Phillipines. pp 65-66.

13. Memon NA (2013) Rice: Important cash crop of Pakistan. Exclusives on Rice. http://www.foodjournal.pk/SeptOct-2013/Sept-Oct-2013-PDF/Exclusive-article-Rice.pdf

14. Shobha RN (2009) Present status of Basmati rice: Prospects for enhancement of its export. In: Proceedings of International Seminar on Basmati Rice; pp:7-9.

15. Verma RC, Singh PK, Arya SS, Kumar V (2017) Evaluation of Basmati Rice Varieties for Yield Performance and Economics under Farmers Field Situation in Muzaffarnagar District. Int.J.Curr.Microbiol.App.Sci. 6: 15521555 . 